\title{
THE EFFECT OF PREPOSITION AND VOCABULARY MASTERY ON STUDENTS' WRITING DESCRIPTIVE TEXT
}

\author{
Teti Herawati ${ }^{1}$ \\ Gustaman Saragih ${ }^{2}$ \\ English Education Program, Universitas Indraprasta PGRI \\ email: jengtet82@gmail.com ${ }^{1}$ \\ email: gustaman.saragih@unindra.ac.id ${ }^{2}$
}

\begin{abstract}
This study aims to determine: 1) The effect of preposition and grammar mastery on students writing descriptive text. 2) The Effect of the preposition on students writing descriptive text. 3) The Effect of vocabulary mastery on students writing descriptive text. The Affordable population is class X of 1 Vocational School Rancaekek, Vocational School Majalayal. The sample of the research is 75 respondents in this study. The method of this current research used surveys. Inference analyses used are random and multiple linear regression. The results of the study show: 1) There is a significant effect of preposition and vocabulary mastery on student writing descriptive text; this is evidenced by the acquisition of Sig. $=0,000<0,05$ and F observe $=9,266 ; 2)$ there is a significant effect of the preposition on student writing descriptive text. This is evidenced by the acquisition of Sig. $=0,011<0,05$ and $T$ observe $=-2,614.3 .3)$ There is a significant effect of vocabulary mastery on students writing descriptive text; this is evidenced by the acquisition of Sig. 0,003<0,05 and T observe $=3,058$.
\end{abstract}

Keywords: preposition, vocabulary mastery, descriptive text

\section{Introduction}

In everyday life, humans cannot escape from language. Language has a significant role in students' intellectual, social, and emotional development and supports success in learning all fields of study. Language learning is expected to help students get to know themselves, their culture, and the culture of others. In addition, language learning is also expected to help students' express ideas and feelings, participate in society, and even discover and use their analytical and imaginative abilities. English is an international language, and its existence is needed in all fields, from work to government. Besides, English also plays a role in communication, technology, politics, education, trade, media, and many other aspects that require English.

The ability to communicate with English in the total sense is the ability to discourse, namely the ability to understand and produce oral and written texts, which are realized in receptive and productive skills. Receptive skills include listening/listening (reading) and reading (reading), while productive skills include speaking (speaking) and writing (writing). Based on these abilities. Writing is among the most important to teach students from an early age in Indonesia, because writing activities can be said to be the most difficult skills for English as a Foreign Language (EFL) students so that students have good writing skills, they must be trained in stages and continuously so that they can get used to pouring their ideas into written form until produce writing.

Concerning writing skills, it is equally essential to provide the broadest opportunities freely about daily activities, especially those related to the surrounding environment, to improve their language skills and expand their vocabulary and vocabulary. All of which will impact the development of ideas or thoughts and mastery of language and even help establish new structures and ideas. These strategies are preferred and help them expand the meaning of a concept at a higher and broader level. 
Writing skill is one of the productive language skills. Writing skills have the exact nature of the ability to speak. Because both are the skills to convey ideas, feelings, and experiences to others using language, some factors that are considered important to support the ability to write descriptions are vocabulary mastery and some supporting aspects such as prepositions, prepositions, and student motivation can also encourage students to be able to write.

As quoted by International Coller-Macmillan that "once in a while a student can master the grammatical form of a language, the next task of students is to master the required vocabulary." No one learns all the words in a language. People know and use words that fit their purpose and continue to learn. Nevertheless, this is a problem in communication; students do not want to communicate both verbally and in writing; this is due to insufficient vocabulary knowledge and the dilator behind physical and psychological factors that can cause different levels of writing skills for each student. Another factor besides vocabulary is the use of prepositions. It is not easy for students in Indonesia because the English system is different from the Indonesian language. It makes students difficult because they need to understand the correct language. Without proper grammar and good vocabulary mastery, writing seems irregular and has no meaning. Students must learn and understand prepositions to make sentences that fit the placement structure. Students who lack an understanding of prepositions will have difficulty in writing English. Based on the explanation above, with all the advantages and disadvantages, the writer is interested in conducting a study entitled "The Effect of Using the Preposition and Vocabulary Mastery on Writing Skills in English Descriptive Texts." This research was conducted at State Vocational School students in Bandung Regency.

\section{Student's Writing Descriptive Texts}

Nainggolan (2012: 4) states that writing expresses ideas, ideas, and thoughts in written form. There is a transfer of ideas in the form of ideas or ideas into written form in writing activities. Based on the description, writing is an activity to express thoughts, ideas, and feelings using written language media to achieve specific goals. Writing is the application of several activities simultaneously, namely the use of words, spelling, and punctuation correctly, the arrangement of sentences so that they are arranged under the contents of thoughts and feelings.

Richards and Schmidt (2002: 532) state, "skill is an acquired ability to perform an activity well." This means the skill is an ability obtained to demonstrate or perform an activity well: thoughts and feelings. While the notion of writing is stated by Linse (2005: 98), namely: "Writing is a combination of process and product. The process refers to the act of gathering ideas and working with them until they are presented in a manner that is polished and comprehensible to readers," which means writing is a combination of process and product. The purpose of the process is to refer to the inclusion of ideas in thought and then assemble them into a series of words that are formed in a smooth bible and easily understood by the reader. Along with this opinion.

While writing is a whole series of activities in expressing ideas and conveying through written language to the reading community to be understood. Based on the description above, it can be concluded that writing skills are an activity to express thoughts, ideas, ideas, and feelings by using written language media to achieve specific goals. Writing skills are the application of several activities simultaneously, namely the use of words, spelling, and punctuation with the right, the arrangement of sentences so that they are arranged in a solid paragraph under the contents of thoughts and feelings.

\section{Definition of Prepositions}

Prepositions in English are part of speech that functions as a preposition or conjunctions in a sentence. Prepositions or prepositions as one type of non-referential words, which are often also called syntactical-semantic task words or structural words, connect constituents in front of them. Prepositions connect nouns, pronouns, or phrases so that they can be arranged into a coherent sentence. The word group in question is a group of words generally not known by morphemic processes and do not contain lexical but grammatical meaning. Prepositions can be classified into particle word classes because their form is relatively unchanged in forming language units larger than words.

Prepositions have various types. There is a preposition that serves to indicate the time, place, direction, object or actor, and tools. Prepositions are also commonly used in a phrase to bring up a new meaning of a verb. It functions to state the relationship between the noun that is preceded with the sentence 
predicate. It can be said that the proposition is a low-ranking predicate. The preposition is in charge of stating the role of the complementary nouns in the higher predicate explicitly.

The Oxford Advanced Learner Dictionary defines that "Preposition is a word or group of words, such as in, from, to, to and on behalf of, used before a noun or pronoun to show place, position, time or method." Prepositions are groups of words such as in, from, to, and on behalf of, used before nouns or pronouns which indicate place, position, time, or method. The essential role of a preposition is to elaborate on a position. This is the direction of location or direction that is more tangible about something specific

Based on the description, the preposition is basically always followed by the noun category and expresses the relationship between the object and the predicate sentence. Furthermore, it can be concluded that the preposition is a word that takes place before a noun and a pronoun to show a relationship. Prepositions are words or groups of words that connect words with other words in a sentence.

\section{Vocabulary Mastery}

Nurgiyantoro (2014: 338) states that vocabulary is the wealth of words owned by a speaker, writer, or language. Vocabulary is also a language component that contains all the information about the meaning and usage of words in the language. In this case, expressive mastery of vocabulary is very influential for students to improve their skills in speaking, especially speaking in English. If a person can apply his English skills in the form of communication in English, it means that his vocabulary is good.

So, from the above theory, students must have at least 3,000 words in English. Vocabulary development is an essential aspect of language development, and the research conducted has proven that proper vocabulary instructions are handy for students' languages. This principle emphasizes direct and indirect teaching; teaching vocabulary before new activities to better master activities while teaching new vocabulary makes it easier for students to reach the targeted vocabulary. Then the right approach needs to be created by an educator so that the English learning process is more exciting and enjoyable without leaving the correct language rules. Students can understand how to speak well and correctly.

\section{Research Methods}

The method used in this research is a descriptive survey with correlation techniques with quantitative approaches. This research variable consists of related variables, namely the ability to write English descriptive text (Y) and two independent variables, namely the use of Prepositions (X1) and vocabulary mastery (X2). According to the framework of thinking and research hypotheses, it is assumed that the independent and dependent variables have a causal relationship and mutually change. For this reason, the constellation model of relationships between variables in this study is as follows:

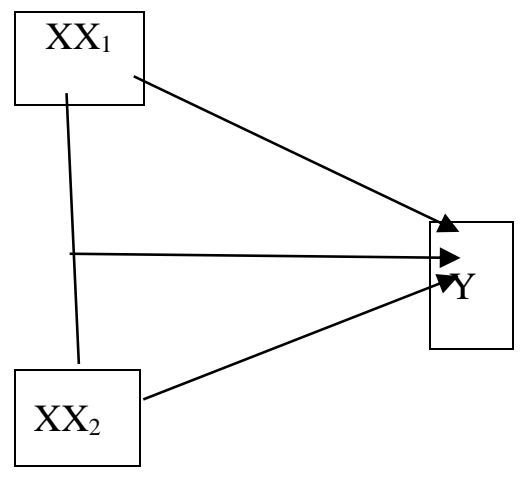

Figure 1. The constellation of relationships between variables

Information.

$\mathrm{X} 1=$ Preposition Use

$\mathrm{X} 2=$ Vocabulary Mastery

$\mathrm{Y}=$ Ability to Write Description English Text. 
The survey method in question is a written test with multiple choice questions for the variable use of prepositions (X1) and vocabulary mastery (X2). The variable ability to write English description text is carried out using a written test. The ability to write the English description text is obtained by using the English description test instrument by spreading the writing description test by selecting one of the five themes given.

\section{Findings and Discussion}

\section{Description of Research Data}

a. Data Writing Skills for Descriptive English Text (Y).

Data on English descriptive text writing skills were obtained from 75 student test scores that became the study sample. The values obtained were the lowest score of 53, the highest score of 93, an average score of 76.33, a median of 78.00, a mode of 78, and a standard deviation of 9,489.

Table 1 Descriptive Text Writing Skills Data Description

\begin{tabular}{|c|c|c|}
\hline \multicolumn{3}{|c|}{ Statistics } \\
\hline \multicolumn{3}{|c|}{ Writing descriptive texts } \\
\hline \multirow{2}{*}{$\mathrm{N}$} & Valid & 75 \\
\hline & Missing & 0 \\
\hline \multicolumn{2}{|c|}{ Mean } & 76,33 \\
\hline \multicolumn{2}{|c|}{ Median } & 78,00 \\
\hline \multicolumn{2}{|c|}{ Mode } & 78 \\
\hline \multicolumn{2}{|c|}{ Std. Deviation } & 9,489 \\
\hline \multicolumn{2}{|c|}{ Skewness } &,- 646 \\
\hline \multicolumn{2}{|c|}{ Std. Error of Skewness } & ,277 \\
\hline \multicolumn{2}{|c|}{ Kurtosis } &,- 227 \\
\hline \multicolumn{2}{|c|}{ Std. error of Kurtosis } & 0,548 \\
\hline \multicolumn{2}{|c|}{ Range } & 40 \\
\hline \multicolumn{2}{|c|}{ Minimum } & 53 \\
\hline \multicolumn{2}{|c|}{ Maximum } & 93 \\
\hline
\end{tabular}

From the above calculation results, it can be said that the ability to write descriptive English texts of State Vocational School students in Bandung Regency is classified as moderate. This is indicated by the acquisition of an average value of 76.33. It is depicted in Figure 1 as follows.

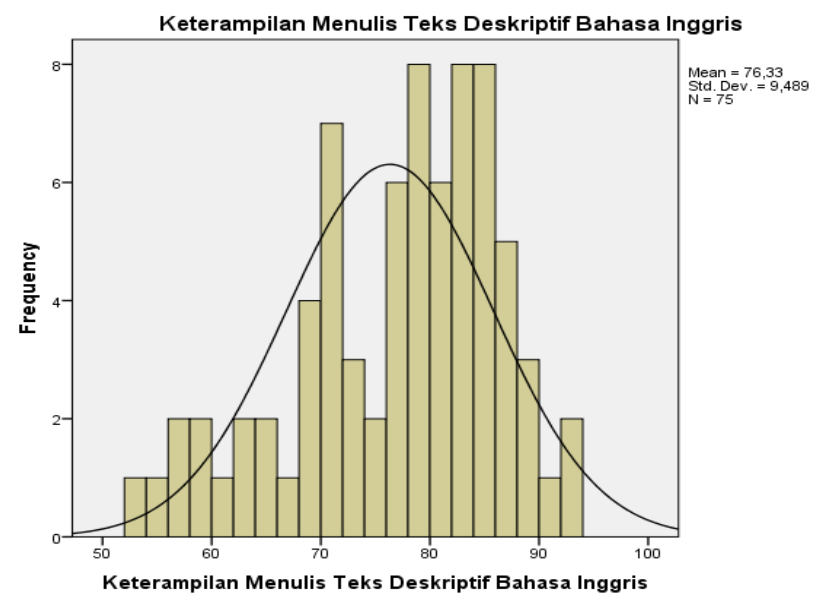

Figure 2. Histogram of Descriptive Text Writing Skills

From the histogram and frequency polygon above, it can be concluded that the writing skills of the descriptive text of State Vocational School students in Bandung Regency have a normal distribution. 


\section{b. Data of Using Preposition (X1)}

Data on the use of prepositions were obtained from 75 student test scores that became the study sample. The values obtained were the lowest score of 40 , the highest score of 75 , the average score of 57.67 , the median of 57.00, the mode of 57a, and the standard deviation of 7.701.

Table 2 Description of Preposition Use Data

\begin{tabular}{|c|c|c|}
\hline \multicolumn{3}{|c|}{ Statistics } \\
\hline \multicolumn{3}{|c|}{ Penggunaan Preposisi } \\
\hline \multirow{2}{*}{$\mathrm{N}$} & Valid & 75 \\
\cline { 2 - 3 } & Missing & 0 \\
\hline Mean & 57,67 \\
\hline Median & 57,00 \\
\hline Mode & $57^{\mathrm{a}}$ \\
\hline Std. Deviation & 7,701 \\
\hline Skewness &,- 170 \\
\hline Std. Error of Skewness &, 277 \\
\hline Kurtosis &,- 016 \\
\hline Std. error of Kurtosis &, 548 \\
\hline Range & 35 \\
\hline Minimum & 40 \\
\hline Maximum & 75 \\
\hline
\end{tabular}

a. Multiple modes exist. The smallest value is shown

From the above calculation results, it can be said that the use of prepositions of State Vocational School students in East Bandung Regency is relatively low. This is indicated by the acquisition of an average value of 57.67. To clarify the data above, it is depicted in the histogram as follows:

From the histogram and frequency polygons above, it can be concluded that the use of prepositions of State Vocational School students in Bandung Regency has a normal distribution.

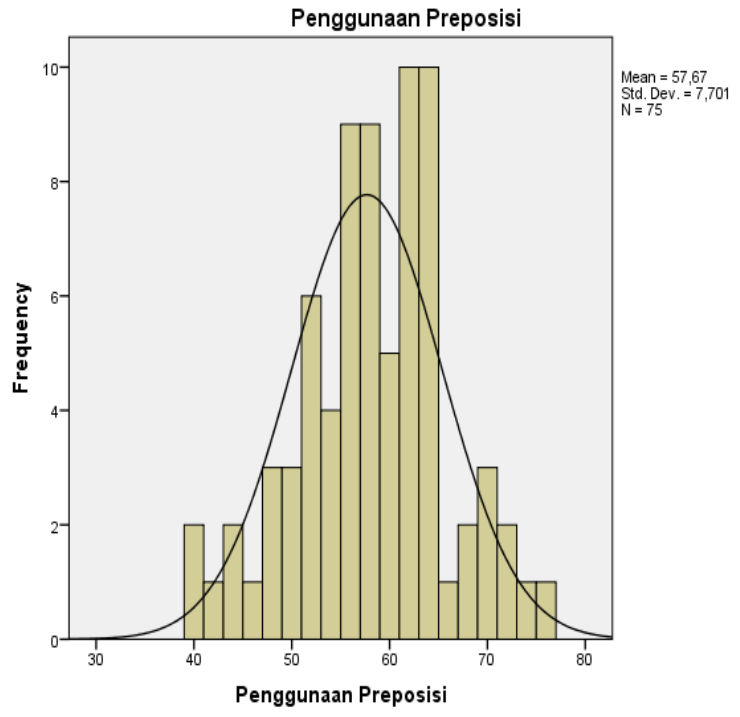

Figure 3. Polygon Histogram Using Prepositions 
c. Data of Vocabulary Mastery (X2)

The vocabulary mastery data was obtained from 75 student test scores that became the study sample. The values obtained were the lowest score of 45 , the highest score of 59, the average score of 52.87, the median of 53.00, the mode of 53, and the standard deviation of 3.757 .

Table 3 Description Data of Vocabulary Mastery

\begin{tabular}{|c|c|c|}
\hline \multicolumn{3}{|c|}{ Statistics } \\
\hline \multicolumn{3}{|c|}{ Vocabulary } \\
\hline \multirow{2}{*}{$\mathrm{N}$} & Valid & 75 \\
\hline & Missing & 0 \\
\hline \multicolumn{2}{|c|}{ Mean } & 52,87 \\
\hline \multicolumn{2}{|c|}{ Median } & 53,00 \\
\hline \multicolumn{2}{|c|}{ Mode } & 53 \\
\hline \multicolumn{2}{|c|}{ Std. Deviation } & 3,757 \\
\hline \multicolumn{2}{|c|}{ Skewness } &,- 207 \\
\hline \multicolumn{2}{|c|}{ Std. Error of Skewness } & 277 \\
\hline \multicolumn{2}{|c|}{ Kurtosis } &,- 619 \\
\hline \multicolumn{2}{|c|}{ Std. error of Kurtosis } & 548 \\
\hline \multicolumn{2}{|c|}{ Range } & 14 \\
\hline \multicolumn{2}{|c|}{ Minimum } & 45 \\
\hline \multicolumn{2}{|c|}{ Maximum } & 59 \\
\hline
\end{tabular}

From the above calculation results, it can be said that the vocabulary mastery of State Vocational School students in Bandung Regency is relatively low. This is indicated by the acquisition of an average value of 52.87. To clarify the data above, it is depicted in the histogram as follows:

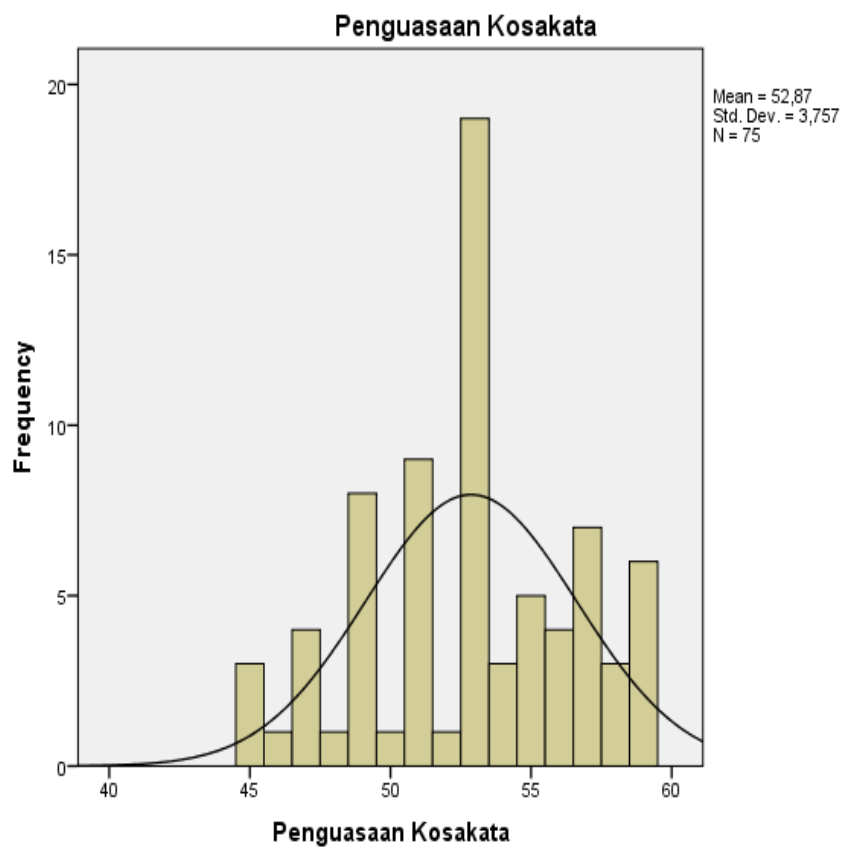

Figure 4. Vocabulary Mastery Histogram

From the histogram and frequency polygons above, it can be concluded that the vocabulary mastery of vocational high school students in Bandung Regency has a normal distribution. 
INFERENCE: Journal of English Language Teaching

Vol. 4, No. 3, December 2021 - March 2022

p-ISSN: 2615-8671

e-ISSN: 2615-868X

\section{Testing Requirements Analysis}

a. Data Normality Test

A good regression requirement if the research data follows the normal distribution.

Table 4 Data Normality Test

\begin{tabular}{|c|c|c|c|c|}
\hline \multicolumn{5}{|c|}{ One-Sample Kolmogorov-Smirnov Test } \\
\hline & & $\begin{array}{c}\text { Penggunaan } \\
\text { Preposisi }\end{array}$ & $\begin{array}{l}\text { Penguasaan } \\
\text { Kosakata }\end{array}$ & $\begin{array}{c}\text { Keterampilan } \\
\text { Menulis Teks } \\
\text { Deskriptif } \\
\text { Bahasa } \\
\text { Inggris }\end{array}$ \\
\hline \multirow{3}{*}{$\begin{array}{l}\text { N } \\
\text { Normal Parameters }\end{array}$} & & 75 & 75 & 75 \\
\hline & Mean & 57,67 & 52,87 & 76,33 \\
\hline & Std. Deviation & 7,701 & 3,757 & 9,489 \\
\hline \multirow[t]{3}{*}{ Most Extreme Differences } & Absolute &, 072 &, 141 & 129 \\
\hline & Positive &, 072 &, 113 &, 056 \\
\hline & Negative &,- 071 &,- 141 &,- 129 \\
\hline Kolmogorov-Smirnov Z & &, 624 & 1,220 & 1,113 \\
\hline Asymp. Sig. (2-tailed) & & 831 & 102 & 167 \\
\hline
\end{tabular}

Table 4 shows that the sig column values are $0.831,0.102$, and 0.167 , which means the value is greater than 0.05 . This means that all data are normally distributed.

\section{b. Multicollinearity Test}

Multicollinearity Test aims to test whether the regression model found a perfect correlation between independent variables. A good regression model should not occur perfect correlation between independent variables. One way to detect the presence of multicollinearity is to look at Tolerance or Variant Inflation Factor (VIF) results. If tolerance $>0.1$ or VIF value $<10$, multicollinearity occurs.

Table 5 Multicollinearity Test Data

\begin{tabular}{|c|c|c|c|}
\hline \multicolumn{4}{|c|}{ Coefficients $^{a}$} \\
\hline & \multirow[t]{2}{*}{ Model } & \multicolumn{2}{|c|}{ Collinearity Statistics } \\
\hline & & Tolerance & VIF \\
\hline \multirow{3}{*}{1} & (Constant) & & \\
\hline & Penggunaan Preposisi & ,984 & 1,017 \\
\hline & Penguasaan Kosakata & ,984 & 1,017 \\
\hline
\end{tabular}

The results of the multicollinearity test in the table above show that Tolerance results are $0.984>0.1$ or Variant Inflation Factor (VIF) $1.017<10$. So, the data did not experience multicollinearity between the use of prepositions and mastery of vocabulary in this multiple regression analysis.

\section{c. Heteroscedasticity Test.}

The meaning of heteroscedasticity is that if there is an error or residual observed, it does not have a constant variant. Heteroscedasticity conditions often occur in cross-section data or data taken from several respondents at a certain time. One method for detecting heteroscedasticity is to make a scatterplot between Standardized Residual (ZRESID) and Standardized Predicted Value (Y cap). The picture below shows there is no change in e along with Y cap, then it is stated there is no heteroscedasticity in error (residual). 


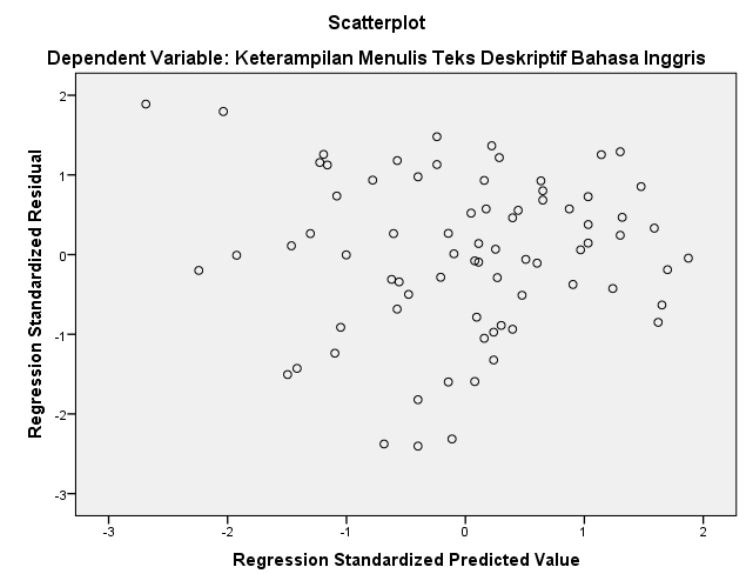

Figure 5. Scatter-plot test for heteroscedasticity

From the picture above shows that the points spread randomly and do not form specific, precise patterns and spread above or below the number 0 on the $\mathrm{Y}$-axis. This shows no heteroscedasticity in the regression model, so it can be used to predict variable skills in writing descriptive English texts based on the use of prepositions and vocabulary mastery.

\section{d. Error Normality Test}

A good requirement is if the research data follows the normal distribution.

Tabel 6. Uji Normalitas Galat

\begin{tabular}{|c|c|c|}
\hline \multicolumn{2}{|c|}{ One-Sample Kolmogorov-Smirnov Test } \\
\hline \multicolumn{2}{|c|}{$\mathrm{N}$} & Unstandardized Residual \\
\hline \multirow{2}{*}{ Normal Parameters ${ }^{\mathrm{a}, \mathrm{b}}$} & Mean & 75 \\
\cline { 2 - 3 } & Std. Deviation & $0 \mathrm{E}-7$ \\
\hline Most Extreme Differences & Absolute &, 076202334 \\
\cline { 2 - 3 } & Positive &, 043 \\
\cline { 2 - 3 } & Negative &,- 070 \\
\hline Kolmogorov-Smirnov Z &, 607 \\
\hline \multicolumn{2}{|c|}{ Asymp. Sig. (2-tailed) } &, 855 \\
\hline \multicolumn{2}{|c|}{ a. Test distribution is Normal. } \\
\hline \multicolumn{2}{|c|}{ b. Calculated from data. } \\
\hline
\end{tabular}

The table above shows that the hypothesis test states that the residual in this regression analysis follows the normal distribution. This is indicated by the value of $\mathrm{Z}=0.607$ and Sig. $=0.855>0.05$. This means that the assumptions or requirements of the regression analysis are fulfilled.

\section{Linearity Test}

\section{a. Regression Linearity the Effect of Variable X1 on Y}

The results of the regression linearity test between the use of prepositions with English descriptive text writing skills, as follows: 
INFERENCE: Journal of English Language Teaching

Vol. 4, No. 3, December 2021 - March 2022

p-ISSN: 2615-8671

e-ISSN: 2615-868X

Table 7 Test Results of Variable Y Regression Linearity over X1

ANOVA Table

\begin{tabular}{|c|c|c|c|c|c|c|c|}
\hline & & & $\begin{array}{l}\text { Sum of } \\
\text { Squares }\end{array}$ & df & Mean Square & $\mathrm{F}$ & Sig. \\
\hline \multirow{5}{*}{$\begin{array}{l}\text { Keterampilan Menulis } \\
\text { Teks Deskriptif Bahasa } \\
\text { Inggris * Penggunaan } \\
\text { Preposisi }\end{array}$} & \multirow[t]{3}{*}{ Between Groups } & (Combined) & 3239,688 & 29 & 111,713 & 1,469 &, 121 \\
\hline & & Linearity & 675,407 & 1 & 675,407 & 8,879 &, 005 \\
\hline & & Deviation from Linearity & 2564,281 & 28 & 91,581 & 1,204 & 284 \\
\hline & \multicolumn{2}{|l|}{ Within Groups } & 3422,979 & 45 & 76,066 & & \\
\hline & \multicolumn{2}{|l|}{ Total } & 6662,667 & 74 & & & \\
\hline
\end{tabular}

Based on the above calculation results, the results of the calculation of Deviation from Linearity with Fcount $=1.204$ and Sig. $=0.284>0.05$. This understanding that the variable use of prepositions with English descriptive text writing skills has a linear relationship.

\section{b. Regression Linearity the Effect of Variable X2 on Y}

The results of the regression linearity test between vocabulary mastery and English descriptive text writing skills are as follows:

Table 8. Test Results of Variable Y Regression Linearity over X2

\begin{tabular}{|c|c|c|c|c|c|c|c|}
\hline \multicolumn{8}{|c|}{ ANOVA Table } \\
\hline & & & $\begin{array}{l}\text { Sum of } \\
\text { Squares }\end{array}$ & df & Mean Square & $\mathrm{F}$ & Sig. \\
\hline \multirow{5}{*}{$\begin{array}{l}\text { Keterampilan Menulis } \\
\text { Teks Deskriptif Bahasa } \\
\text { Inggris * Penguasaan } \\
\text { Kosakata }\end{array}$} & Between Groups & (Combined) & 1881,402 & 14 & 134,386 & 1,686 & .083 \\
\hline & & Linearity & 860,883 & 1 & 860,883 & 10,803 &, 002 \\
\hline & & Deviation from Linearity & 1020,519 & 13 & 78,501 &, 985 & .476 \\
\hline & Within Groups & & 4781,264 & 60 & 79,688 & & \\
\hline & Total & & 6662,667 & 74 & & & \\
\hline
\end{tabular}

Based on the above calculation results obtained from the Linearity Deviation results with $\mathrm{F} 0=$ 0.985 and Sig. $=0.476>0.05$. This understanding that the vocabulary mastery variable with English descriptive text writing skills has a linear relationship.

\section{Research Hypothesis Test and Discussion of Research Results}

The results of calculations and tests can be seen in the table below:

Table 9. Calculation Results for Multiple Correlation Coefficient Testing Variables X1 and $\mathrm{X} 2$ with respect to $\mathrm{Y}$

Model Summary

\begin{tabular}{|l|r|r|r|r|}
\hline Model & R & R Square & $\begin{array}{c}\text { Adjusted R } \\
\text { Square }\end{array}$ & $\begin{array}{c}\text { Std. Error of } \\
\text { the Estimate }\end{array}$ \\
\hline 1 &, $452^{\text {a }}$ &, 205 &, 183 & 8,579 \\
\hline
\end{tabular}
a. Predictors: (Constant), Penguasaan Kosakata,
Penggunaan Preposisi

Table 10. Calculation Results for the Significance of Regression Coefficients Variables X1 and $\mathrm{X} 2$ with respect to $\mathrm{Y}$

ANOVA $^{a}$

\begin{tabular}{|ll|r|r|r|r|r|}
\hline \multicolumn{1}{|c|}{} & \multicolumn{1}{c|}{$\begin{array}{c}\text { Sum of } \\
\text { Model }\end{array}$} & Squares & df & Mean Square & F & Sig. \\
\hline 1 & Regression & 1363,835 & 2 & 681,917 & 9,266 &, $000^{6}$ \\
& Residual & 5298,832 & 72 & 73,595 & & \\
& Total & 6662,667 & 74 & & & \\
\hline
\end{tabular}

a. Dependent Variable: Keterampilan Menulis Teks Deskriptif Bahasa Inggris

b. Predictors: (Constant), Penguasaan Kosakata, Penggunaan Preposisi 
INFERENCE: Journal of English Language Teaching

Vol. 4, No. 3, December 2021 - March 2022

p-ISSN: 2615-8671

e-ISSN: 2615-868X

Table 11. Results of Calculation of Multiple Regression Equations Variables X1 and X2 with respect to $Y$

Coefficients $^{\text {a }}$

\begin{tabular}{|c|c|c|c|c|c|c|}
\hline \multirow{2}{*}{\multicolumn{2}{|c|}{ Model }} & \multicolumn{2}{|c|}{ Unstandardized Coefficients } & \multirow{2}{*}{$\begin{array}{c}\text { Standardized } \\
\text { Coefficients } \\
\text { Beta } \\
\end{array}$} & \multirow[b]{2}{*}{$t$} & \multirow[b]{2}{*}{ Sig. } \\
\hline & & $B$ & Std. Error & & & \\
\hline \multirow[t]{3}{*}{1} & (Constant) & 52,746 & 16,883 & & 3,124 &, 003 \\
\hline & Penggunaan Preposisi &,- 341 &, 131 &,- 277 & $-2,614$ &, 011 \\
\hline & Penguasaan Kosakata & 818 & ,268 &, 324 & 3,058 &, 003 \\
\hline
\end{tabular}

a. Dependent Variable: Keterampilan Menulis Teks Deskriptif Bahasa Inggris

Table 12. Correlation: Zero-order and Partial

\begin{tabular}{|c|c|c|c|}
\hline \multirow{2}{*}{ Model } & \multicolumn{3}{|c|}{ Correlations } \\
\cline { 2 - 4 } & Zero-order & Partial & Part \\
\hline (Constant) & & &,- 275 \\
Penggunaan Preposisi &,- 318 &,- 294 &, 321 \\
Penguasaan Kosakata &, 359 &, 339 & -39 \\
\hline
\end{tabular}

a. Dependent Variable: Keterampilan Menulis Teks Deskriptif Bahasa Inggris

a. The effect of the use of prepositions (X1) and mastery of vocabulary (X2) together on the skills of writing descriptive English text ( $Y$ )

Hypothesis tested:

$\mathrm{H} 0: \beta \mathrm{y} 1=\beta \mathrm{y} 2=0$

$\mathrm{H} 1: \beta \mathrm{y} 1 \neq 0$ and $\beta \mathrm{y} 2 \neq 0$

Meaning:

$\mathrm{H} 0$ : There is no influence of the use of prepositions (X1) and mastery of vocabulary (X2) together on descriptive text writing skills (Y).

$\mathrm{H1}$ : There is an influence of the use of prepositions (X1) and mastery of vocabulary (X2) together on the ability to write descriptive texts (Y)

From Table 10, it can be stated that there is a significant influence of the use of prepositions and mastery of vocabulary on the skills of writing descriptive English texts. This is evidenced by the acquisition of Sig. $0,000 \mathrm{~b}<0.05$ and Fcount $=9.266$. This shows that Ho is not acceptable, meaning H1 is accepted. This means that there is a significant influence on the use of prepositions (X1) and mastery of vocabulary (X2) together on the skills of writing descriptive English texts.

From the calculation above, the double regression line equation results can be stated with $=52.746$ $0341 \mathrm{X} 1+0.818 \mathrm{X} 2$. This understanding that the increase in one variable using prepositions and vocabulary mastery will increase the skills of writing descriptive texts amounted to 0.341 for variables X1 and 0.818 for X2. From Table 9, it can also be explained that together with the variable use of prepositions and vocabulary mastery contributed $20.5 \%$ to the variable skills in writing descriptive English texts.

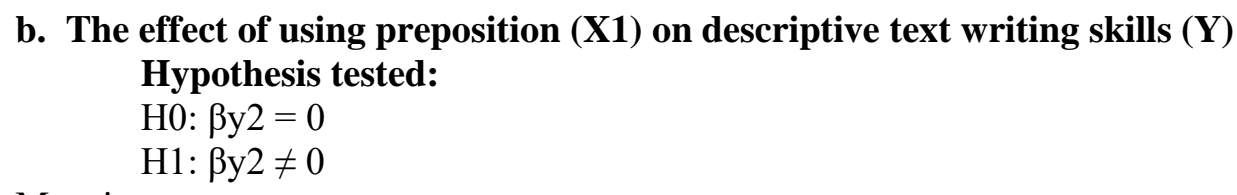

Meaning:

Ho: There is no influence on the use of prepositions on the skills of writing descriptive English texts H1: There is an influence of the use of prepositions on the skills of writing descriptive English texts

From Table 11. it can be stated that there is a significant influence on the use of prepositions in writing descriptive English texts. This is evidenced by the acquisition of Sig. $0.011<0.05$ and $t_{\text {count }}=-$ 
INFERENCE: Journal of English Language Teaching

Vol. 4, No. 3, December 2021 - March 2022

p-ISSN: 2615-8671

e-ISSN: 2615-868X

2.614. This shows that Ho is not acceptable, meaning H1 is accepted. The contribution of the variable use of the preposition to English descriptive text writing skills can be stated by the formula:

$\mathrm{RY}, \mathrm{X} 2=$ Beta2 $\mathrm{x}$ coefficient. YX2 correlation

$\mathrm{RY}, \mathrm{X} 2=0.40 \times 0.77=0.308$

From the results of the above calculation, it can be stated that the contribution of using prepositions in improving English descriptive text writing skills is $31 \%$

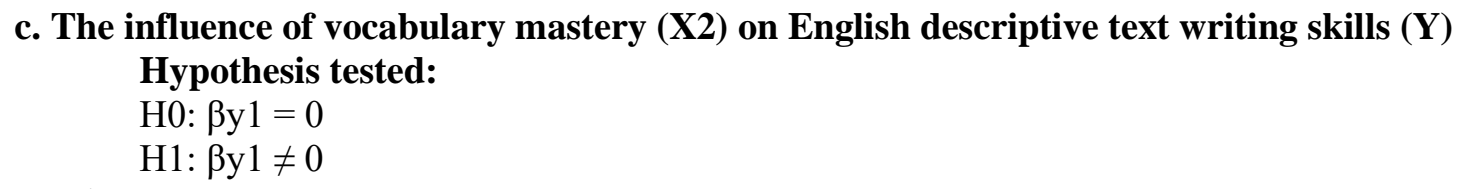

Meaning:

Ho: There is no influence on the mastery of vocabulary on the skills of writing descriptive English texts

H1: There is an influence of the mastery of vocabulary on the skills of writing descriptive English texts

From table 4.11. it can be stated that there is a significant influence on the mastery of vocabulary on writing descriptive English texts. This is evidenced by the acquisition of Sig. $0.003<0.05$ and tcount $=$ 3.058. This shows that Ho is not acceptable, meaning H1 is accepted. The formula can state the contribution of vocabulary mastery variables to English descriptive text writing skills:

$\mathrm{RY}, \mathrm{X} 1=$ Beta1 $\mathrm{x}$ coefficient. $\mathrm{YX} 1$ correlation

$\mathrm{RY}, \mathrm{X} 1=0.63 \times 0.86=0.54$

From the above calculation results, it can be stated that the contribution of mastery of vocabulary in improving the skills of writing descriptive English texts by 54\%. As with other languages, vocabulary is an important element that must be mastered even in learning English. This statement is by what was stated by Richards and Schmidt (2002: 4) that "vocabulary is one of the most obvious components of language." This means that vocabulary is one of the most specific language components. When a person has an extensive vocabulary, he will be able to use the language well. Related to this statement, Tarigan (2013:2) states that "the quality of one's language skills depends on the quantity and quality of the vocabulary they have." The more vocabulary a person has, the greater the language skills. In this case, it has been proven that the mastery of vocabulary influences writing descriptive English texts. In other words, the better the vocabulary mastery, the better the writing skills.

\section{Conclusions}

There is a significant effect of preposition and vocabulary mastery together towards students' writing descriptive text at Vocational School students in Bandung, and this is evidenced by the acquisition of Sig. $=0,000<0,05$ and $F_{\text {observe }}=9,266$. Second, there is a significant effect of prepositions on writing English descriptive text at Vocational School students in Bandung. The acquisition of Sig evidence this. $=$ $0,011<0,05$ and $\mathrm{T}_{\text {observe }}=-2,614.3$. Finally, there is a significant effect of vocabulary mastery towards the skill to write English descriptive text at Vocational School students in Bandung; the acquisition of Sig evidence this. $0,003<0,05$ and $\mathrm{T}$ observe $=3,058$.

\section{References}

Linse, C. T. (2005). Practical English Language Teaching Young learners. New York: McGraw-Hill. Nurgiyantoro, B. (2014). Penilaian dalam pengajaran bahasa dan sastra. Yogyakarta: BPFE.

Richards, J.C. \& Schmidt R. (2002). Longman Dictionary of Language Teaching and Applied Linguistics, $3^{\text {rd }}$ Ed. London: Pearson Education Ltd.

Sugiyono. (2015). Statistik nonparametriks untuk penelitian. Bandung: Alfabeta.

Sugiyono. (2016). Metode penelitian kuantitatif kualitatif dan $R \& D$. Bandung: Alfabeta.

Tarigan, H.G. (2013). Menulis sebagai Suatu keterampilan berbahasa. Bandung: Angkasa. 